\title{
Statyba
}

\section{LOCKING CONDITIONS FOR FINITE ELEMENT MODELS}

\section{S. Kalanta \& R. Fliotovienè}

To cite this article: S. Kalanta \& R. Fliotoviene (1997) LOCKING CONDITIONS FOR FINITE ELEMENT MODELS, Statyba, 3:9, 57-65, DOI: 10.1080/13921525.1997.10531672

To link to this article: https://doi.org/10.1080/13921525.1997.10531672

曲 Published online: 26 Jul 2012.

Submit your article to this journal

山 Article views: 37 


\section{LOCKING CONDITIONS FOR FINITE ELEMENT MODELS}

\section{S. Kalanta, R. Fliotovienè}

\section{Introduction}

Mathematical models of a locking body stress and strain analysis and optimization problems include the locking conditions $[1,2]$. The locking conditions must be satisfied at all points of the body. It is impossible to realize these conditions by solving such problems by means of mumerical methods. By using the finite element method the locking conditions usually are satisfied only in the nodals of the finite elements, where the so-called point locking conditions are introduced $[3,4]$. However, the point locking conditions are only one of the possible discrete locking expressions. The classical discretization methods, namely point collocation, area collocation and Bubnov's-Galerkin's methods for the discretization of elastic-plastic body yield conditions are proposed in papers $[5,6]$. On the basis of the above methods, three forms of discrete yield conditions are developed, namely the point, the element-integral and the point-integral yield conditions. It has been shown that the most stable and exact design results are obtained by using the point-integral yield conditions [6,7]. In this article three new discrete locking conditions for the finite element models are developed on the basis of the three above techniques.

\section{Locking conditions for the finite element}

The finite element of volume $V_{k}$ of a linearly locking body is analysed in the $\mathrm{x} \equiv\left\{x_{1}, x_{2}, x_{3}\right\}^{T}$ coordinate system. The any point strain state of the element is described by the vector $\varepsilon_{k}(x)$, then the locking conditions read

$$
\varphi=\varphi_{0}\left(\varepsilon_{0 k}(\mathbf{x})\right)-\varphi\left(\varepsilon_{k}(\mathbf{x})\right)+[D] \lambda_{k}(\mathbf{x}) \geq \mathbf{0}
$$

where $\varphi\left(\varepsilon_{k}(x)\right)$ is a locking function, $\varepsilon_{0 k}(x)$ is the function of locking constants (the extreme compression deformations), $[D]$ is a locking surface translation (locking) matrix, $\lambda_{k}(x)$ is a multiplier function, related to the locking function $\varepsilon_{k}(x)$. In general, all the functions are described as vectorfunctions. The multipliers $\lambda_{k}(x)$ are related to the associated law of locking function by

$$
\dot{\sigma}_{k}(\mathbf{x})=\left[\frac{\partial \varphi\left(\varepsilon_{k}(\mathbf{x})\right)}{\partial \varepsilon_{k}(\mathbf{x})}\right]^{T} \lambda_{k}(\mathbf{x})
$$

where $\dot{\sigma}_{k}(\mathrm{x})$ is a vector function of the stress rates, $\left[\frac{\partial \varphi\left(\varepsilon_{k}(x)\right)}{\partial \varepsilon_{k}(x)}\right]$ is a locking functions gradient matrix.

The locking conditions (1) must be satisfied in the all points of the finite element. But it is impossible to solve analysis and optimization problems of the locking body by means of numerical methods. Therefore this strong requirement is weakened. Verifying the locking conditions only at the nodes of the finite elements, the locking conditions (1) at many points of the element are not satisfied. But one must note that the point locking conditions

$$
\varphi_{i}=\varphi_{0 i}\left(\varepsilon_{0, k i}\right)-\varphi_{i}\left(\varepsilon_{k i}\right)+[D] \lambda_{k i} \geq 0
$$

are only one of the forms of the weak locking conditions. By using the collocation method, the general form of the weak locking conditions is developed:

$\int_{V_{k}}\left[G_{k}(\mathbf{x})\right]\left\{\varphi_{0}\left(\varepsilon_{0 k}(\mathbf{x})\right)-\varphi\left(\varepsilon_{k}(\mathbf{x})\right)\right\}+[D] \lambda_{k}(\mathbf{x}) \geq \mathbf{0 , ( 3 )}$

where $\left[G_{k}(\mathbf{x})\right]$ is a weight functions matrix formed from the diagonal submatrices $\left[G_{k i}(\mathbf{x})\right]$, related to 
the nodes $i=1,2, \ldots, s$ of the finite element. The discrete expression of the conditions (3) is developed further. The approximation functions for the displacements $\mathbf{u}_{k}(\mathbf{x})$ and multipliers $\lambda_{k}(\mathbf{x})$ are presented as

$$
\begin{aligned}
& \mathbf{u}_{k}(\mathbf{x})=\left[H_{u k}(\mathbf{x})\right] \mathbf{u}_{k}, \\
& \lambda_{k}(\mathbf{x})=\left[H_{\lambda k}(\mathbf{x})\right] \lambda_{k}
\end{aligned}
$$

while for the locking constant as

$$
\varepsilon_{0 k}(\mathbf{x})=\left\{\mathbf{H}_{0 k}(\mathbf{x})\right\}^{T} \varepsilon_{0 k} .
$$

Here $\quad \mathbf{H}_{0 k}(\mathbf{x}) \equiv\left\{H_{0 k 1}(\mathbf{x}), H_{0 k 2}(\mathbf{x}), \ldots, H_{0 k s}(\mathbf{x})\right\}^{T}$ is a vector of shape functions of locking constant; $\left[H_{u k}(\mathbf{x})\right],\left[H_{\lambda k}(\mathbf{x})\right]$ are the approximation matrices for the displacements and the multipliers $\lambda_{k}(x)$, formed from the submatrices $\left[H_{u k i}(\mathbf{x})\right],\left[H_{\lambda k i}(\mathbf{x})\right]$ respectively. The vectors $u_{k}, \lambda_{k}, \varepsilon_{0 k}$ are vector of the displacements, vector of the multipliers and vector the locking constants for the individual finite element respectively. The components of these vectors are the vectors of the nodal displacements $\mathbf{u}_{k i}$, the vectors of multipliers $\lambda_{k i}$ and the vectors of the locking constants $\varepsilon_{0 k i}$ respectively, where $i=1,2, \ldots, s$.

By using the geometric equations, the strains are expressed via the displacements:

$$
\boldsymbol{\varepsilon}_{k}(\mathbf{x})=[\mathscr{A}]^{T} \mathbf{u}_{k}(\mathbf{x})=\left[B_{k}(\mathbf{x})\right] \mathbf{u}_{k},
$$

where

$$
\left[B_{k}(\mathbf{x})\right]=[\mathscr{A}]^{T}\left[H_{u k}(\mathbf{x})\right] .
$$

Here $[\mathscr{A}]^{T}$ is a differential operator of geometric equations. The locking function

$$
\varphi\left(\varepsilon_{k}(\mathbf{x})\right)=\varphi_{u}\left(\mathbf{u}_{k}(\mathbf{x})\right)
$$

By integrating the conditions (3) and by taking into account the relationships (5)-(7), the following discrete expression of locking conditions for the finite element is obtained:

$$
\varphi_{0 k}\left(\varepsilon_{0 k}\right)-\varphi_{k}\left(\mathbf{u}_{k}\right)+\left[D_{k}\right] \lambda_{k} \geq \mathbf{0},
$$

where

$$
\begin{aligned}
& \begin{aligned}
\varphi_{k}\left(\mathbf{u}_{k}\right) & =\iint_{V_{k}}\left[G_{k}(\mathbf{x})\right] \varphi\left(\varepsilon_{k}(\mathbf{x})\right) d V_{k}= \\
& =\int_{V_{k}}\left[G_{k}(\mathbf{x})\right] \varphi_{u}\left(\mathbf{u}_{k}(\mathbf{x})\right) d V_{k},
\end{aligned} \\
& \varphi_{0 k}\left(\varepsilon_{0 k}\right)=\int_{V_{k}}\left[G_{k}(\mathbf{x})\right] \varphi_{0}\left(\varepsilon_{0 k}(\mathbf{x})\right) d V_{k}, \\
& {\left[D_{k}\right]=\int_{V_{k}}\left[G_{k}(\mathbf{x})\right][D]\left[H_{\lambda k}(\mathbf{x})\right] d V_{k} .}
\end{aligned}
$$

Choosing various weight functions, one obtains various discrete locking functions (8) with the different expressions of the vectors $\varphi_{k}\left(\mathbf{u}_{k}\right)$, $\varphi_{0 k}\left(\varepsilon_{0 k}\right)$ and of the matrix $\left[D_{k}\right]$. The weight functions can be chosen by using the classical collocation methods $[6,8]$.

Applying the point collocation method, it is taken that $\left[G_{k i}\left(\mathbf{x}_{i}\right)\right]=[I]$ for the element nodal point $i$ and that $\left[G_{k i}\left(\mathbf{x}_{j}\right)\right]=[0]$ for remainder it points $i \neq j$. Here $[I],[0]$ are the unit and zero matrices respectively. Then the locking conditions of the element are expressed via the locking conditions (2) of its nodes $i=1,2, \ldots, s$. The components of the vectors $\boldsymbol{\varphi}_{k}\left(\mathbf{u}_{k}\right)$ and $\boldsymbol{\varphi}_{0 k}\left(\varepsilon_{0 k}\right)$ are the functions $\boldsymbol{\varphi}_{k i}\left(\mathbf{u}_{k}\right), \boldsymbol{\varphi}_{0 k i}\left(\varepsilon_{0 k i}\right)$. The matrix $\left[D_{k}\right]=[\operatorname{diag}[D]]$.

By using the area (element) collocation method for discretization of locking conditions, the unit weight functions $\left[G_{k}(\mathbf{x})\right]=[I]$ constant in the element volume are applied. Then

$$
\begin{array}{cc}
\varphi_{k}\left(\mathbf{u}_{k}\right)=\int_{V_{k}} \Phi_{u}\left(\mathbf{u}_{k}(\mathbf{x})\right) d V_{k} \leq \varphi_{0 k}\left(\varepsilon_{0 k}\right)+\left[D_{k}\right] \lambda_{k} \\
\text { where } \quad \varphi_{0 k}\left(\varepsilon_{0 k}\right)=\int_{V_{k}} \varphi_{0}\left(\varepsilon_{0 k}(\mathbf{x})\right) d V_{k} \\
& {\left[D_{k}\right]=\int_{V_{k}}[D]\left[H_{\lambda k}(\mathbf{x})\right] d V_{k}}
\end{array}
$$

An analysis of the yield conditions [6,7] provides that the best approximation of the inequalities can be obtained by choosing the weight function according to the Bubnov's-Galerkin's method. Applying this method the matrix $\left[G_{k i}(\mathbf{x})\right]=[I]\left[H_{j k i}(\mathbf{x})\right] \quad$ is introduced for the each node $i=1,2, \ldots, s$ of the element. Here $\left[H_{j k i}(\mathbf{x})\right]$ is a highest displacement 
order shape function corresponding to node $i$. Then the locking conditions (8) for the whole element are expressed by the locking integral conditions of its nodes:

$$
\begin{aligned}
\boldsymbol{\varphi}_{k i}\left(\mathbf{u}_{k}\right) & =\int_{V_{k}}\left[G_{k i}(\mathbf{x})\right] \Phi_{u}\left(\mathbf{u}_{k}(\mathbf{x})\right) d V_{k} \leq \\
& \leq \Phi_{0 k i}\left(\varepsilon_{0 k}\right)+\left[D_{k i}\right] \lambda_{k},
\end{aligned}
$$

where

$$
\begin{gathered}
\varphi_{0 k i}\left(\varepsilon_{0 k}\right)=\int_{V_{k}}\left[G_{k i}(\mathbf{x})\right] \varphi_{0}\left(\varepsilon_{0 k}(\mathbf{x})\right) d V_{k}, \\
{\left[D_{k i}\right]=\int_{V_{k}}\left[G_{k i}(\mathbf{x})\right][D]\left[H_{\lambda k}(\mathbf{x})\right] d V_{k} ;} \\
i=1,2, \ldots, s .
\end{gathered}
$$

For this case

$$
\begin{aligned}
\varphi_{0 k}\left(\varepsilon_{0 k}\right) & \equiv\left\{\Phi_{0 k 1}\left(\varepsilon_{0 k}\right), \Phi_{0 k 2}\left(\varepsilon_{0 k}\right), \ldots, \Phi_{0 k s}\left(\varepsilon_{0 k}\right)\right\}^{T}, \\
\boldsymbol{\varphi}_{k}\left(\mathbf{u}_{k}\right) & \equiv\left\{\boldsymbol{\Phi}_{k 1}\left(\mathbf{u}_{k}\right), \Phi_{k 2}\left(\mathbf{u}_{k}\right), \ldots, \Phi_{k s}\left(\mathbf{u}_{k}\right)\right\}^{T}
\end{aligned}
$$

and the matrix $\left[D_{k}\right]$ consists of the submatrices $\left[D_{k i}\right]$. Thus the pattern of the vectors $\varphi_{0 k}\left(\varepsilon_{0 k}\right)$ and $\Phi_{k}\left(\mathbf{u}_{k}\right)$ in the discrete locking conditions (8), formed by using the point collocation and Bubnov'sGalerkin's methods are identic, but the component expressions differ.

It is obvious that the simplest for an application are the point collocation conditions, and the most complicated are the point-integral ones (15). But it is possible to build simplified integral locking conditions expressions, additionaly introducing the approximation of the locking function:

$$
\boldsymbol{\varphi}_{k}\left(\mathbf{u}_{k}(\mathbf{x})\right)=\left[H_{\varphi k}(\mathbf{x})\right] \bar{\Phi}_{k}\left(\mathbf{u}_{k}\right),
$$

where $\bar{\varphi}_{k}\left(\mathbf{u}_{k}\right) \equiv\left\{\boldsymbol{\Phi}_{k 1}\left(\mathbf{u}_{k}\right), \Phi_{k 2}\left(\mathbf{u}_{k}\right), \ldots, \boldsymbol{\varphi}_{k i}\left(\mathbf{u}_{k}\right), \ldots\right.$, $\left.\boldsymbol{\varphi}_{k s}\left(\mathbf{u}_{\mathrm{k}}\right)\right\}^{T}, \boldsymbol{\varphi}_{k i}\left(\mathbf{u}_{\mathrm{k}}\right)$ is the locking function of the $i$ - th node. Then the following simplified analogues of the conditions (12) ir (15) are obtained:

$$
\begin{gathered}
\varphi_{k}\left(\mathbf{u}_{k}\right)=\left[\Phi_{k}\right] \overline{\boldsymbol{\varphi}}_{k}\left(\mathbf{u}_{k}\right) \leq \varphi_{0_{k}}\left(\varepsilon_{0_{k}}\right)+\left[D_{k}\right] \lambda_{k}, \\
\varphi_{k i}\left(\mathbf{u}_{k}\right)=\left[\Phi_{k i}\right] \overline{\boldsymbol{\varphi}}_{k}\left(\mathbf{u}_{k}\right) \leq \varphi_{0 k i}\left(\varepsilon_{0_{k}}\right)+\left[D_{k i}\right] \lambda_{k},
\end{gathered}
$$

$\left[\Phi_{k}\right]=\int_{V_{k}}\left[H_{\varphi k}(\mathbf{x})\right] d V_{k},\left[\Phi_{k i}\right]=\int_{V_{k}}\left[G_{k i}(\mathbf{x})\right]\left[H_{\varphi k}\right] d V_{k}$

Here the locking conditions of the element (18) and the locking conditions of the $i$-th node (19) are expressed by the algebraic sum of all element nodes locking conditions (2), multiplied by certain weight coefficients.

When the unknown values in the problem are the residual displacements $u_{r k}(x)$ and the strains $\varepsilon_{r k}(x)$ instead of the total displacements functions (4) the following function must be accepted:

$$
\mathbf{u}_{e k}(\mathbf{x})=\left[H_{u k}(\mathbf{x})\right] \mathbf{u}_{e k}, \quad \mathbf{u}_{r k}(\mathbf{x})=\left[H_{u k}(\mathbf{x})\right] \mathbf{u}_{r k} .
$$

Then the element discrete conditions

$$
\varphi_{0 k}\left(\varepsilon_{0 k}\right)-\varphi_{k}\left(u_{e k}+u_{r k}\right)+\left[D_{k}\right] \lambda_{k} \geq 0
$$

can be obtained from (8) by changing the arguments of the functions according to the formulae $\mathbf{u}_{k}(\mathbf{x})=\mathbf{u}_{e k}(\mathbf{x})+\mathbf{u}_{r k}(\mathbf{x})$ and $\mathbf{u}_{k}=\mathbf{u}_{e k}+\mathbf{u}_{r k}$. Here $\mathbf{u}_{e k}$ is the displacement vector, obtained by solving the elasticity problem.

For the perfectly plastic-rigid body the matrix $[D]=[0]$. Thus the finite element locking conditions for such body

$$
\varphi_{0 k}\left(\varepsilon_{0 k}\right)-\varphi_{k}\left(\mathbf{u}_{k}\right) \geq 0
$$

also are obtained from (8) taking that $\left[D_{k}\right]=[0]$.

\section{Numerical example}

In order to illustrate the discretization of the locking conditions, the discrete expressions of the energy locking conditions $[2,4]$

$$
\varepsilon_{0}^{2}(\mathbf{x})-\varepsilon_{11}^{2}(\mathbf{x})-\varepsilon_{22}^{2}(\mathrm{x})+\varepsilon_{11}(\mathrm{x}) \varepsilon_{22}(\mathrm{x})-3 \varepsilon_{12}^{2}(\mathrm{x}) \geq 0
$$

for the triangle finite element of perfectly plasticrigid body at the plane strain state wwe'll develop. Here the locking function has the form:

$$
\begin{aligned}
\varphi\left(\varepsilon_{k}(\mathbf{x})\right)= & \varepsilon_{11}^{2}(\mathbf{x})+\varepsilon_{22}^{2}(\mathbf{x})-\varepsilon_{11}(\mathbf{x}) \varepsilon_{22}(\mathbf{x})+ \\
& +3 \varepsilon_{12}^{2}(\mathbf{x})=\varepsilon(\mathbf{x})^{T}[\Pi] \varepsilon(\mathbf{x})
\end{aligned}
$$


and $\varphi_{0}\left(\varepsilon_{0 k}(\mathbf{x})\right)=\varepsilon_{0 k}^{2}(\mathbf{x})$, where the strain vector is $\varepsilon(\mathbf{x})=\left\{\varepsilon_{11}(\mathbf{x}), \varepsilon_{11}(\mathbf{x}), \varepsilon_{12}(\mathbf{x})\right\}^{T}$ and

$$
[\Pi]=\left[\begin{array}{ccc}
1 & -0.5 & 0 \\
-0.5 & 1 & 0 \\
0 & 0 & 3
\end{array}\right]
$$

The relation between displacements and strains is described by geometric equations:

$$
\left.\begin{array}{l}
\varepsilon_{11}(\mathbf{x})=\frac{\partial u_{1}(\mathbf{x})}{\partial x_{1}}, \quad \varepsilon_{22}(\mathbf{x})=\frac{\partial u_{2}(x)}{\partial x_{2}} \\
\varepsilon_{12}(x)=\frac{\partial u_{1}(x)}{\partial x_{2}}+\frac{\partial u_{2}(x)}{\partial x_{1}}
\end{array}\right\}
$$

The locking constant along the element is assumed to be $\varepsilon_{0 k}(\mathbf{x})=\varepsilon_{0 k}=$ const .

$A$ first order triangle element. It is convenient to consider the first order triangle element in the local $\xi=\left\{\xi_{1}, \xi_{2}, \xi_{3}\right\}^{T}$ (area ratio) coordinate system $[5,8]$. Applying this coordinate system, the position of any point $D$ of the element is described by rations of the certain triangles $A_{k i}$ (Fig. 1) to the total area of the element $A_{k}$ :

$$
\xi_{1 d}=\frac{A_{k 1}}{A_{k}}, \quad \xi_{2 d}=\frac{A_{k 2}}{A_{k}}, \quad \xi_{3 d}=\frac{A_{k 3}}{A_{k}} .
$$

The relation between the local and global coordinates $\mathrm{I}$ is described by following relationships:

$$
\begin{aligned}
& \xi_{1}=\frac{a_{1}+b_{1} x_{1}+c_{1} x_{2}}{2 A_{k}}, \quad \xi_{2}=\frac{a_{2}+b_{2} x_{1}+c_{2} x_{2}}{2 A_{k}}, \\
& \xi_{3}=\frac{a_{3}+b_{3} x_{1}+c_{3} x_{2}}{2 A_{k}} .
\end{aligned}
$$

Here the element area is

$$
A_{k}=a_{1}+a_{2}+a_{3}
$$

and the coefficients are:

$$
\begin{aligned}
& a_{1}=x_{12} x_{23}-x_{13} x_{22}, \\
& a_{2}=x_{13} x_{21}-x_{11} x_{23}, \\
& a_{3}=x_{11} x_{22}-x_{12} x_{21},
\end{aligned}
$$

$$
\begin{array}{ll}
b_{1}=x_{22}-x_{23}, & c_{1}=x_{13}-x_{12}, \\
b_{2}=x_{23}-x_{21}, & c_{2}=x_{11}-x_{13}, \\
b_{3}=x_{21}-x_{22}, & c_{3}=x_{12}-x_{11} .
\end{array}
$$

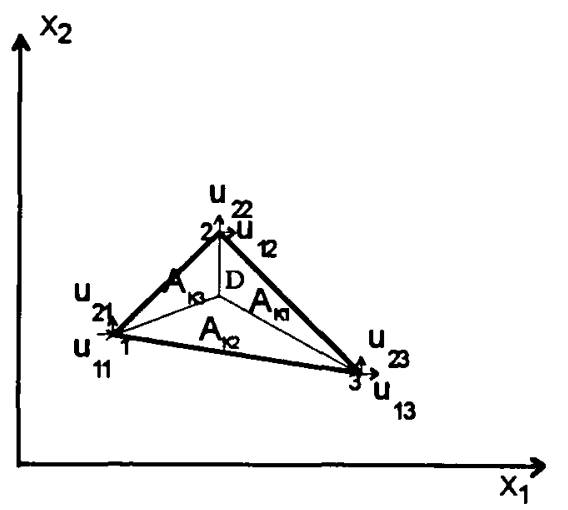

Fig. 1. The first order element

The displacements of the finite element are approximated by linear functions

$$
\begin{aligned}
& u_{1 k}(\xi)=\xi_{1} u_{11}+\xi_{2} u_{12}+\xi_{3} u_{13}=\sum_{i=1}^{3} \xi_{i} u_{1 i}, \\
& u_{2 k}(\xi)=\xi_{1} u_{21}+\xi_{2} u_{22}+\xi_{3} u_{23}=\sum_{i=1}^{3} \xi_{i} u_{2 i}, .
\end{aligned}
$$

The strains of the element are calculated by using the complicated function differential formula

$$
\begin{aligned}
\frac{\partial u_{i}(\xi)}{\partial x_{j}}= & \frac{\partial u_{i}(\xi)}{\partial \xi_{1}} \cdot \frac{\partial \xi_{1}(\mathbf{x})}{\partial x_{j}}+\frac{\partial u_{i}(\xi)}{\partial \xi_{2}} \cdot \frac{\partial \xi_{2}(\mathbf{x})}{\partial x_{j}}+ \\
& +\frac{\partial u_{i}(\xi)}{\partial \xi_{3}} \cdot \frac{\partial \xi_{3}(\mathbf{x})}{\partial x_{j}} .
\end{aligned}
$$

The strains

$$
\begin{array}{r}
\varepsilon_{11, k}=\frac{1}{2 A_{k}}\left(b_{1} u_{11}+b_{2} u_{12}+b_{3} u_{13}\right), \\
\varepsilon_{22, k}=\frac{1}{2 A_{k}}\left(c_{1} u_{21}+c_{2} u_{22}+c_{3} u_{23}\right), \\
\varepsilon_{12, k}=\frac{1}{2 A_{k}}\left(c_{1} u_{11}+b_{1} u_{21}+c_{2} u_{12}+\right. \\
\left.+b_{2} u_{22}+c_{3} u_{13}+b_{3} u_{23}\right)
\end{array}
$$

are the costant in the area of the element, so the locking conditions for all the points of the element are the same. Thus for any discretization method we have only one locking condition for each element:

$$
\psi_{k}=\gamma_{k}\left(\varepsilon_{0 k}^{2}-\varepsilon_{11, k}^{2}-\varepsilon_{22, k}^{2}+\varepsilon_{11, k} \varepsilon_{22, k}-3 \varepsilon_{12, k}^{2}\right) \geq 0 .
$$


The coefficient $\gamma_{k}$ depends on the discretization method: for the point collocation case $\gamma_{k}=1$, for the element integral condition (the area collocation) $\gamma_{k}=A_{k}$ and for the point integral condition $\gamma_{k}=\frac{A_{k}}{3}$. The solution of the problem independs on the coefficient $\gamma_{k}$, that's why it is convienent to take that $\gamma_{k}=1$.

The second order triangle element. The displacement functions of the second order element (Fig. 2) are approximated by quadratic polynoms:

$$
u_{1 k}(\xi)=\sum_{i=1}^{6} H_{k i}(\xi) u_{1 i}, \quad u_{2 k}(\xi)=\sum_{i=1}^{6} H_{k i}(\xi) u_{2 i} .
$$

The shape functions for the displacements $H_{k i}(\xi)=2 \xi_{i}^{2}-\xi_{i}$ for the nodes $i=1,2,3$ and $H_{k 4}(\xi)=4 \xi_{1} \xi_{2}, H_{k 5}(\xi)=4 \xi_{2} \xi_{3}, H_{k 6}(\xi)=4 \xi_{1} \xi_{3}$. The displacement approximation matrix $\left[H_{u k}(\xi)\right]$ and the vector $u_{k}$ consist of the submatrices $\left[H_{u k i}(\xi)\right]=[I] H_{k i}(\xi)$ and of the subvectors $\mathbf{u}_{k i}$ when analysing the element in a clockwise direction, starting from the first node. Here $[I]$ is the second order unit matrix

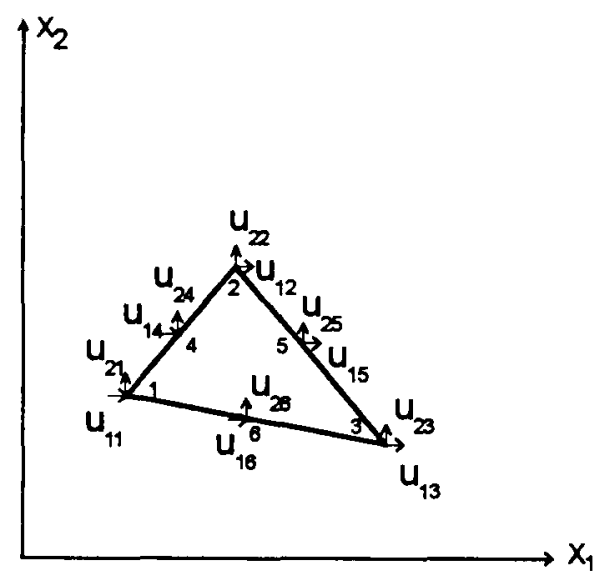

Fig. 2. The second order element

By differentiating the displacement functions, the element relation matrix between strains $\varepsilon_{k}(\xi)$ and nodal displacements $u_{k}$ is obtained:

$$
\left[A_{k}(\xi)\right]^{T}=\left[\begin{array}{cccccccccccc}
\alpha_{1} & 0 & \alpha_{4} & 0 & \alpha_{2} & 0 & \alpha_{5} & 0 & \alpha_{3} & 0 & \alpha_{6} & 0 \\
0 & \beta_{1} & 0 & \beta_{4} & 0 & \beta_{2} & 0 & \beta_{5} & 0 & \beta_{3} & 0 & \beta_{6} \\
\beta_{1} & \alpha_{1} & \beta_{4} & \alpha_{4} & \beta_{2} & \alpha_{2} & \beta_{5} & \alpha_{5} & \beta_{3} & \alpha_{3} & \beta_{6} & \alpha_{6}
\end{array}\right],
$$

where

$$
\begin{array}{ll}
\alpha_{1}=\frac{b_{1}}{2 A_{k}}\left(4 \xi_{1}-1\right), & \alpha_{4}=\frac{2\left(\xi_{2} b_{1}+\xi_{1} b_{2}\right)}{A_{k}}, \\
\alpha_{2}=\frac{b_{2}}{2 A_{k}}\left(4 \xi_{2}-1\right), & \alpha_{5}=\frac{2\left(\xi_{3} b_{2}+\xi_{2} b_{3}\right)}{A_{k}}, \\
\alpha_{3}=\frac{b_{3}}{2 A_{k}}\left(4 \xi_{3}-1\right), & \alpha_{6}=\frac{2\left(\xi_{3} b_{1}+\xi_{1} b_{3}\right)}{A_{k}}, \\
\beta_{1}=\frac{c_{1}}{2 A_{k}}\left(4 \xi_{1}-1\right), & \beta_{4}=\frac{2\left(\xi_{2} c_{1}+\xi_{1} c_{2}\right)}{A_{k}}, \\
\beta_{2}=\frac{c_{2}}{2 A_{k}}\left(4 \xi_{2}-1\right), & \beta_{5}=\frac{2\left(\xi_{3} c_{2}+\xi_{2} c_{3}\right)}{A_{k}}, \\
\beta_{3}=\frac{c_{3}}{2 A_{k}}\left(4 \xi_{3}-1\right), & \beta_{6}=\frac{2\left(\xi_{3} c_{1}+\xi_{1} c_{3}\right)}{A_{k}} .
\end{array}
$$

Applying the formula (22), the locking function reads

$$
\varphi\left(\varepsilon_{k}(\xi)\right)=\mathbf{u}_{k}^{T}\left[B_{k}(\xi)\right] \mathbf{u}_{k},
$$

where the matrix

$$
\left[B_{k}(\xi)\right]=\left[A_{k}(\xi)\right][\Pi]\left[A_{k}(\xi)\right]^{T} .
$$

According to the formulae (8)-(15) the following element conditions are obtained

a) the point conditions -

$$
\begin{aligned}
& \boldsymbol{\varphi}_{k i}\left(\mathbf{u}_{k}\right)=\mathbf{u}_{k}^{T}\left[A_{k i}\left(\xi_{i}\right)\right][\Pi]\left[A_{k i}\left(\xi_{i}\right)\right]^{T} \mathbf{u}_{k} \leq \varepsilon_{0 k i}^{2}, \\
& i=1,2, \ldots, 6 \text {; }
\end{aligned}
$$

b) the integral conditions according to area collocation method -

$$
\boldsymbol{\Phi}_{k}\left(\mathbf{u}_{k}\right)=\mathbf{u}_{k}^{T}\left[\Phi_{k}\right] \mathbf{u}_{k} \leq A_{k} \varepsilon_{0 k}^{2}
$$

or in the simplified version

$$
\mathbf{H}_{k}^{T} \bar{\varphi}_{k}\left(\mathbf{u}_{k}\right) \leq A_{k} \varepsilon_{0 k}^{2},
$$

where

$$
\begin{aligned}
{\left[\boldsymbol{\Phi}_{k}\right]=\int\left[A_{A_{k}}\left[B_{k}(\xi)\right] d A_{k}, \quad \mathbf{H}_{k}=\int_{A_{k}} \mathbf{H}_{\varphi k}(\xi) d A_{k},\right.} & (30) \\
\overline{\boldsymbol{\varphi}}_{k}\left(\mathbf{u}_{k}\right)= & \left\{\boldsymbol{\Phi}_{k 1}\left(\mathbf{u}_{k}\right), \boldsymbol{\varphi}_{k 2}\left(\mathbf{u}_{k}\right), \ldots, \boldsymbol{\Phi}_{k 6}\left(\mathbf{u}_{k}\right)\right\}^{T}, \\
\boldsymbol{\Phi}_{k i}\left(\mathbf{u}_{k}\right) & =\mathbf{u}_{k}^{T}\left[A_{k i}\left(\xi_{i}\right)\right][\mathbf{[}]\left[A_{k i}\left(\xi_{i}\right)\right]^{T} \mathbf{u}_{k}= \\
& =\mathbf{u}_{k}^{T}\left[B_{k i}\left(\xi_{i}\right)\right] \mathbf{u}_{k}
\end{aligned}
$$




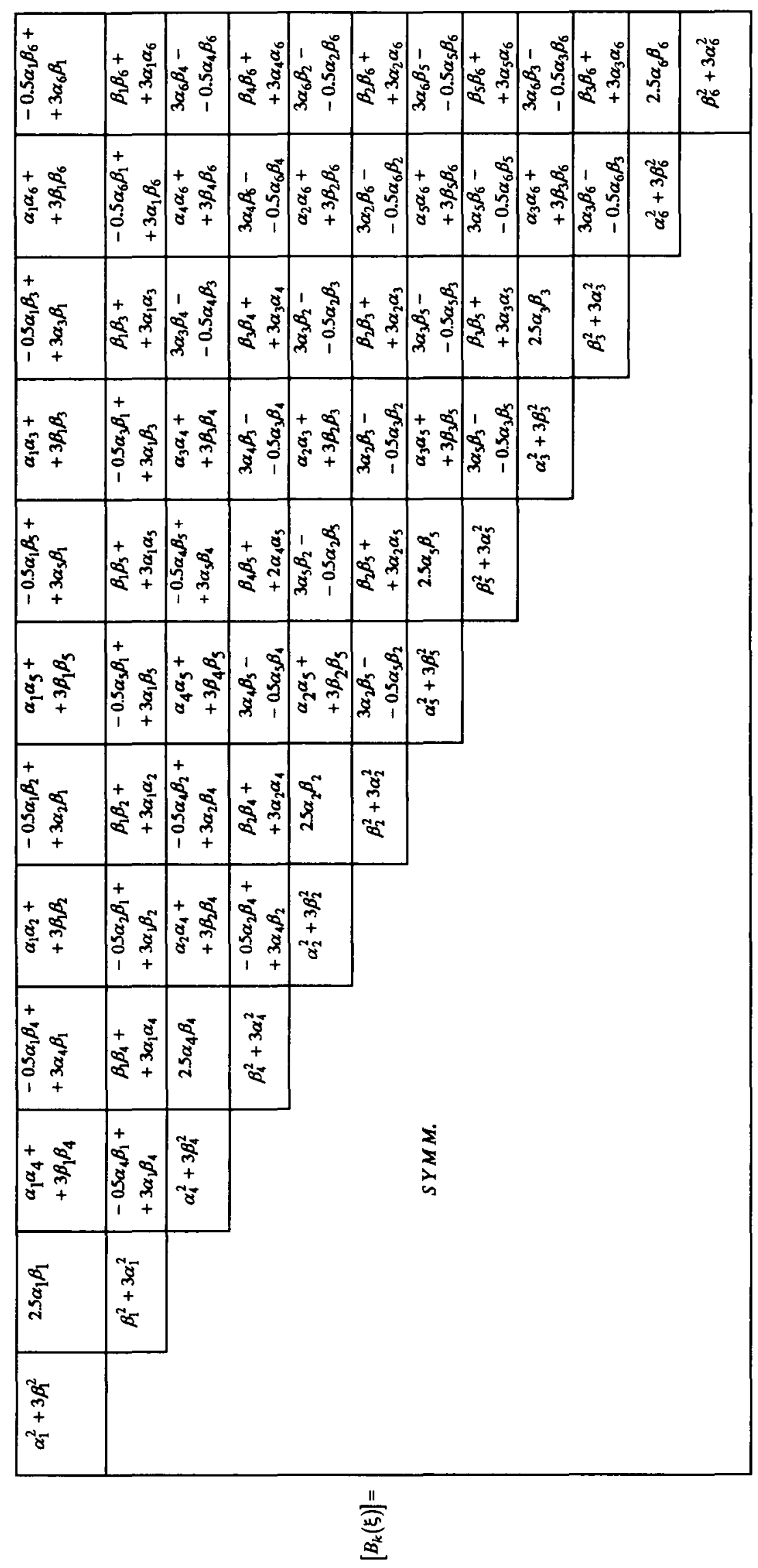




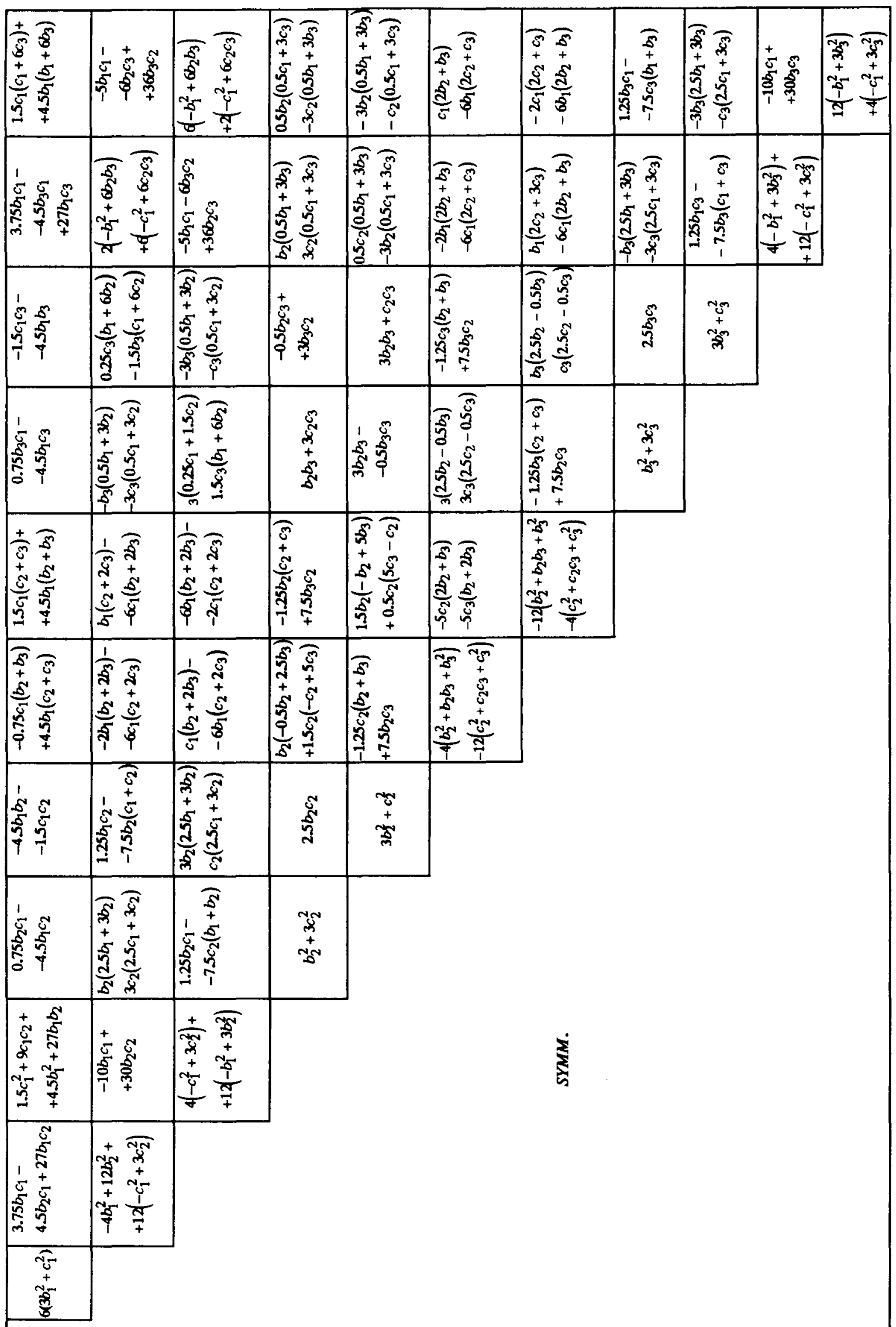


c) the point integral conditions according to the Bubnov's-Galerkin's method

$\Phi_{k i}\left(\mathbf{u}_{k}\right)=\mathbf{u}_{k}^{T}\left[\Phi_{k i}\right] \mathbf{u}_{k} \leq A_{k i} \varepsilon_{0 k}^{2}, \quad i=1,2, \ldots, 6$

or in the simplified version

$$
\mathbf{H}_{k i}^{T} \bar{\Phi}_{k}\left(\mathbf{u}_{k}\right) \leq A_{k i} \varepsilon_{0 k}^{2},
$$

where

$$
\begin{aligned}
& {\left[\mathbf{\Phi}_{k i}\right]=\int_{A_{k}} H_{k i}(\xi)\left[B_{k}(\xi)\right] d A_{k}, A_{k i}=\int_{A_{k}} H_{k i}(\xi) d A_{k},} \\
& \mathbf{H}_{k i}=\int_{A_{k}} H_{k i}(\xi) \mathbf{H}_{\phi k}(\xi) d A_{k} .
\end{aligned}
$$

The displacement shape functions $H_{k i}(\xi)$ are accepted as the weight functions $G_{k i}(\xi)$ in order to form the point integral locking functions. The simplified and the integral locking conditions for the finite element nodes $i=1,2, \ldots, 6$ are developed. The formula

$$
\int_{A_{k}} \xi_{1}^{a} \xi_{2}^{b} \xi_{3}^{c} d A_{k}=\frac{a ! b ! c !}{(a+b+c+2) !} 2 A_{k}
$$

or the standard subroutines [9] can be used for the numerical integration of the above matrices.

Due to the large amount one can not present the all expresions of the matrices $\left[\Phi_{k}\right]$ and $\left[\Phi_{k i}\right]$. The locking condition matrix $\left[\Phi_{k 1}\right]$ for first node of the element is presented only. Another matrices one can obtain by integrating the denoted matrices. Thereto one can form the second and the third nodes locking matrices $\left[\Phi_{k 2}\right]$ and $\left[\Phi_{k 3}\right]$ from the matrix $\left[\Phi_{k 1}\right]$ cyclically translating its element indices respectively. For the matrix check one can use the condition

$$
\left[\Phi_{k}\right]=\sum_{i=1}^{6}\left[\Phi_{k i}\right]
$$

The simplified locking conditions are presented:

a) the element integral condition -

$$
\frac{A_{k}}{3}\left\{\boldsymbol{\varphi}_{k 4}\left(\mathbf{u}_{k}\right)+\varphi_{k s}\left(\mathbf{u}_{k}\right)+\varphi_{k 6}\left(\mathbf{u}_{k}\right)\right\} \leq A_{k} \varepsilon_{0 k}^{2}
$$

b) the point integral condition -

$$
\left[\Gamma_{k}\right] \bar{\varphi}_{k}\left(\mathbf{u}_{k}\right) \leq \mathbf{C}_{0 k}
$$

where

$$
\begin{gathered}
{\left[\Gamma_{k}\right]=\frac{A_{k}}{180}\left[\begin{array}{rccccc}
6 & 0 & -1 & -4 & -1 & 0 \\
0 & 32 & 0 & 16 & -4 & 16 \\
-1 & 0 & 6 & 0 & -1 & -4 \\
-4 & 16 & 0 & 32 & 0 & 16 \\
-1 & -4 & -1 & 0 & 6 & 0 \\
0 & 16 & -4 & 16 & 0 & 32
\end{array}\right],} \\
\mathrm{C}_{0 k}=\frac{A_{k} \varepsilon_{0 k}^{2}}{3} \times\left\{\begin{array}{lllll}
0,1, & 0,1, & 0,1
\end{array}\right\}^{T}
\end{gathered}
$$

Here the expressions of the functions $\varphi_{k i}\left(u_{k}\right)$ are obtained according to the formula (31) inserting the values of local coordinates.

\section{Conclusions}

Three clasic collocation techniques for the locking conditions discretization are applied, namely the point collocation method, the area collocation method and the Bubnov's-Galerkin's method. On the basis of the above methods three locking conditions for the finite element are developed, namely the point conditions, the integral element conditions and the point integral conditions. Using the approximation functions of the displacements and locking multipliers, this conditions are expressed by nodal displacements and multipliers of finite element. The simplest is the point locking function expression, but the most exact are those of integral point conditions. The locking function discretization is illustrated by the numerical example. The discrete locking condition for the first and the second order plate element with the linear and the parabolic displacement distributions are developed. It has been shown that all three discrete locking conditions for the first order element coincide.

\section{References}

1. А.ирас. Теория огтимизации в предельном анализе твердого деформируемого тела. Вильнюс: Минтис, 1971. $124 \mathrm{c}$.

2. А.ирас, Р.И.Флетовене. Теория затвердевания. Вильнюс: Техника, 1995. $73 \mathrm{c}$.

3. Р.И.Флетовене. Метод конечных элементов в задаче анализа линейно-затвердевающих систем // Науч. 
труды вузов Литвы. Сер. Литовский механический сборник, № 32, 1990, с. 4453.

4. А.Иирас, АЭ.Боркаускас. Поверочный расчет идеально пластично-жесткого тела при плоском деформированном состоянии // Науч. труды вузов Литвы. Сер. Литовский механический сборник, № $1(2), 1973$, c. $73-87$.

5. S.Kalanta.Takumo sąlygos baigtinių elementy modeliams // 4-os tarptautinès konferencijos "Naujos statybinès medžiagos, konstrukcijos ir technologijos" medžiaga. Vilnius: Technika, 1995, p. 260-265.

6. С.Калаята. Двойственные математические модели задач анализа упругопластических конструкций с разрывными полями перемещений // Statyba (Стронтельство), № 3(3), Вильнос: Техника, 1995, с. 5-29.

7. С.Каланта. Равновесные конечно-элементные постановки задат расчета и оптимизация предельной нагрузхи // Statyba (Строительство), № 3(7), Вильнос: Техника, 1996, с. 13-23.

8. О.Зенкевич. Метод конечных элементов в технике. M: Mup, 1975. 541 c.

9. R.Belevicius, R.Kulvietiene and G.Kulvietis. Generaling Matrices of Finite Elements Using Computer Algebra System Vibran // Fifth Nordic Seminar on Computational Mechanics. Aalborg, November 5-6, 1992, p. 78-81.

Iteikta 19970125

\section{STANDĖJIMO SĄLYGOS BAIGTINIŲ ELEMENTŲ MODELIAMS}

\section{S.Kalanta, R.Fliotoviené}

\section{Santra u ka}

Sprendžjant standèjančio kūno ịtempimy-deformaciju analizès ar optimizacijos uždavinius, standèjimo sąlygos paprastai tikrinamos tik baigtiniu elementy mazguose, ty. sudaromos taškinès standejjimo sqlygos. Tačiau plastiškumo teorijoje naudojami ir kiti takumo sąlygy analogai, diskretizacijos metodai. Siame straipsnyje standéjimo sąlygu diskretizacijos problema sprendžiama panaudojant klasikinius matematikoje žinomus kolokaciju metodus. Taškinès kolokacijos, kolokaciju srityje ir Bubnovo-Galiorkino metodais sudarytos trys bendros diskretiniy standèjimo sąlygu formos - taškinès, integralinès elementinès ir integralinès taškinès standèjimo sąlygos. Bendru atveju užduodant poslinkių, standèjimo konstanty ir daugikliy aproksimavimo funkcijas, jos išreiškiamos per baigtinio elemento mazgu poslinkius, standejjimo konstantas ir daugiklius. Kūno deformaciju būvi tiksliausiai aprašo integralinès taškinès standẻjimo sąlygos, tačiau paprasčiausia yra taškinès standejjimo sąlygos išraǐ̌ka. Aprašytoji standéjimo sąlygų diskretizacija iliustruojama plokštes pirmos ir antros eiles trikampio elemento su tiesiniu ir paraboliniu poslinkiu pasiskirstymu diskretiniu standèjimo sąlygu sudarymu. Parodyta, kad pirmos eilès elemento visos trys diskretinių standèjimo sq̨lygu išraiškos sutampa iki pastovaus daugiklio.

Stanislovas KALANTA Doctor, Associate Professor. Department of Structural Mechanics. Vilnius Gediminas Technical University, 11 Sauletekio Ave, 2040 Vilnius, Lithuania.

Doctor Engineering (structural mechanics), 1974. Research visits to: Leningrad Polytechnic Institute, Moscow Civil Engineering Institute, Kiev Civil Engineering Institute. Research interests: computational mechanics, finite element method, analysis and optimization of elasticplastic structures.

Rasa FLIOTOVIENE. Doctor, Associate Professor. Department of Structural Mechanics. Vilnius Gediminas Technical University, 11 Saulètekio Ave, 2040 Vilnius, Lithuania.

Civil engineer, 1984. Doctor Engineering (structural mechanics), 1990. Research interests: computational mechanics, analysis and optimization of locking structures. 